\title{
The 3-methylhistidine content of human tissues
}

\author{
BY M. ELIA, A. CARTER ANDR. SMITH \\ Metabolic Unit, Nuffield Orthopaedic Centre, Oxford \\ (Received 25 June 1979 - Accepted 18 July 1979)
}

\begin{abstract}
1. The amount of 3-methylhistidine (3-MeH) has been measured in eighty-eight samples of tissue taken post-mortem from five adults.

2. The highest concentration ( $\mu \mathrm{mol} / \mathrm{g}$ fat-free dry weight) of $3-\mathrm{MeH}$ was in skeletal muscle $(3 \cdot 3 \mathrm{I} \pm 0.05)$; intermediate values (2-3) were found in cardiac muscle and those tissues containing smooth muscle; and low values (less than 1 ) occurred in parenchymal tissues such as liver and kidney.

3. There was little variation between the mean $3-\mathrm{MeH}$ content of striated muscles in different individuals, and no significant difference between the $3-\mathrm{MeH}$ concentrations of striated muscles taken from six different sites.

4. The results suggest that it is justifiable to use values obtained from single muscles to calculate the rate of myofibrillar breakdown from urinary 3 -MeH excretion.
\end{abstract}

3-methylhistidine (3-MeH), first identified in human urine by Tallan et al. (1954) and found in actin and myosin 13 years later (Asatoor \& Armstrong, 1967; Johnson et al. 1967), is increasingly being used to indicate the rate of breakdown of these myofibrillar proteins (Young \& Munro, 1978). This is because 3-MeH is formed by the post-translational methylation of peptide-bound histidine, and when the protein which contains it is broken down $3-\mathrm{MeH}$ is excreted quantitatively as the free amino-acid in the urine. Thus its rate of excretion gives an estimate of breakdown rate of myofibrillar protein. However the accuracy of this estimate depends on several factors, such as the completeness of the $24 \mathrm{~h}$ urine collections, the control of diet, and a knowledge of the 3-MeH content of muscle. This study is concerned with the last-mentioned factor. In measurements of $3-\mathrm{MeH}$ excretion after injury (Williamson et al. 1977), we calculated the myofibrillar protein breakdown rate assuming the $3-\mathrm{MeH}$ content of muscle to be $\mathrm{I} .6 \mu \mathrm{mol} / \mathrm{g}$ fat-free dry weight (Asatoor \& Armstrong, 1967). Subsequent work (Bilmazes et al. 1978; Holbrook et al. 1979; Tomas et al. 1979), has shown this value to be an underestimate, and in consequence calculation of muscle protein breakdown falsely high. We have therefore measured the 3-MeH content of several tissues obtained from adults post-mortem in order to compare it with the published values from human muscle, to examine variations between individuals and from one muscle to another, and to investigate the $3-\mathrm{MeH}$ content of non-muscular tissues.

\section{EXPERIMENTAL}

Tissue samples were taken within $24 \mathrm{~h}$ of sudden death from five adults (Table I). Four had died from myocardial infarction and one from head injury. Major fascia and blood vessels were removed from the samples and areas of cardiac and cerebral infarction were avoided. In addition to these tissues, samples from three cell cultures (human lymphoblastoid, monkey kidney and rabbit aortic endothelial cells) and a liver cell preparation (Berry \& Friend, 1969) were also examined. The samples were analysed by the method of Haverberg et al. (1975). The dried hydrolysed sample was dissolved in $0.15 \mathrm{M}$-lithium citrate buffer, $\mathrm{pH} 2.2$ to a concentration of about $2 \mathrm{mg} / \mathrm{ml}$ and $\mathrm{I} 00 \mu \mathrm{l}$ applied to a Chromaspek $\mathrm{J}_{\mathrm{I}} 80$ aminoacid analyser (Rank Hilger) fitted with a standard column at a temperature of $60^{\circ}$. Almost 
Table I. The amount ( $\mu$ mollg fat-free dry weight) of 3-MeH in the tissues of five adults

Subject no...

Sex. .

Age (years). .

Cause of death. .

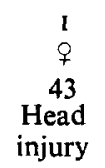

3
8
63 infarction
Group $\mathrm{I}(3-\mathrm{MeH}>3.0 \mu \mathrm{mol} / \mathrm{g}$ fat-free dry weight
Tissues

\section{Muscle}

Pectoralis major

Rectus abdominis

Latissimus dorsi

Intercostal

Quadriceps fernoris

Psoas

Diaphragmatic

$\begin{array}{llllll} & & & & \text { Mean } & \text { SEM } \\ 3.60 & 3.58 & 3.38 & 3.58 & 3.41 & 0.13 \\ 3.90 & 3.18 & 3.10 & 3.40 & 3.38 & 0.14 \\ 3.34 & 3.44 & 3.26 & 3.18 & 3.32 & 0.05 \\ 3.53 & 3.20 & 3.31 & 3.71 & 3.29 & 0.17 \\ 3.23 & 3.06 & 3.39 & 3.89 & 3.20 & 0.17 \\ 3.10 & 3.90 & 3.23 & 3.52 & 3.16 & 0.10 \\ - & 3.23 & 3.61 & 2.70 & 3.00 & 0.26\end{array}$

Group 2 (3- $\mathrm{MeH} 1-3 \mu \mathrm{mol} / \mathrm{g}$ fat-free dry weight)

Large intestine
Heart muscle
Small intestine
Oesophagus
Stomach
Prostate
Major vein*

\begin{tabular}{lcccccc}
$\mathrm{I} .06$ & 2.28 & 2.04 & 2.13 & 1.97 & 1.98 & 0.22 \\
- & 1.93 & 1.80 & 1.70 & 2.28 & 1.93 & 0.13 \\
$\mathrm{I} .91$ & 1.63 & - & 1.92 & 1.43 & 1.72 & 0.12 \\
- & - & - & 1.58 & - & 1.58 & \\
- & - & 1.25 & 1.74 & - & 1.49 & \\
\hline- & - & 1.49 & - & - & 1.49 & \\
1.0 & 1.49 & $1.4 \mathrm{I}$ & 0.80 & 1.88 & 1.32 & 0.19
\end{tabular}

Group 3 (3-MeH $<1 \cdot 0 \mu \mathrm{mol} / \mathrm{g}$ fat-free dry weight)

$\begin{array}{lccccccc}\text { Spleen } & 1.43 & 1.00 & - & 0.74 & 0.73 & 0.98 & 0.16 \\ \text { Skin } & 0.53 & 0.60 & 0.49 & 0.65 & 0.57 & 0.57 & 0.03 \\ \text { Lung } & 0.14 & 0.59 & 0.80 & 0.30 & 0.65 & 0.50 & 0.12 \\ \text { Liver } & - & 0.41 & 0.48 & 0.44 & 0.56 & 0.47 & 0.03 \\ \text { Brain } & 0.15 & 0.55 & 0.60 & - & 0.40 & 0.43 & 0.10 \\ \text { Testes } & - & - & 0.42 & 0.44 & - & 0.43 & \\ \text { Kidney } & - & 0.45 & 0.51 & 0.37 & 0.27 & 0.36 & 0.06 \\ \text { Ovary } & - & 0.27 & - & - & - & 0.27 & \\ \text { Thyroid } & - & - & 0.17 & 0.27 & - & 0.22 & \end{array}$

* The samples comprised either the femoral vein or the lower part of the inferior vena cava.

complete resolution of $3-\mathrm{MeH}$ from histidine was obtained, without prior pyridine elution, using a lithium citrate buffer $(0.2 \mathrm{M}, \mathrm{pH} 6.5)$ and a lithium borate buffer $(0.3 \mathrm{M}, \mathrm{pH} \mathrm{I} \cdot 5)$.

\section{RESULTS}

In Table $\mathrm{I}$ the patients are arranged in order of age, and the results have been separated into three groups according to their $3-\mathrm{MeH}$ content (expressed as $\mu \mathrm{mol} / \mathrm{g}$ fat-free dry weight). The mean values for skeletal muscle showed little variation from one individual to another, and there was no significant difference in the mean concentration of $3-\mathrm{MeH}$ for each of the striated muscles examined. The mean $( \pm \mathrm{SE}$ ) value for skeletal muscle for the whole group was $3.31 \pm 0.05$. The two groups with a lower content of $3-\mathrm{MeH}$ than skeletal muscle, included (as expected) cardiac muscle and non-muscular tissues. In group no. 3 the apparently wide variation in $3-\mathrm{MeH}$ content from one individual to another may be partly due to experimental error at these low concentrations. The cell cultures and liver cell preparation contained variable amounts of $3-\mathrm{MeH}\left(0.12-0.3^{8} \mu \mathrm{mol} / \mathrm{g}\right.$ fat-free dry weight). 
DISCUSSION

Skeletal muscle contains most of the $3-\mathrm{MeH}$ in the body. This is because of the high concentration of $3-\mathrm{MeH}$ in muscle and its large mass relative to other tissues (Munro, 1978). In order to make quantitative assumptions about the turnover of muscle from the urinary $3-\mathrm{MeH}$ excretion it is clearly important to have comprehensive information about the concentrations within it. Variation in this concentration may be apparent, due to experimental error or to changes in the ratio, myofibrillar proteins: sarcoplasmic and stromal proteins; or real, due to variation in the extent of methylation of histidine, as in foetal or cardiac myosin (Huszar \& Elzinga, 1972). The factors which control the extent of methylation of peptide-bound histidine are unknown; in actin methylation appears to be constant, but may be variable in myosin. We consider that in our patients the small variations for skeletal muscle are probably due to experimental error and do not reflect alterations in its composition or extent of methylation. In man we would not expect to find the differences seen in other animals where red and white muscles are separate and $3-\mathrm{MeH}$ is absent from red muscle myosin. Our results strongly suggest that the methylation of all skeletal muscle is constant and that it is valid to use a mean value for the calculation of muscle breakdown from $3-\mathrm{MeH}$ excretion. There is still some doubt about what the exact value should be. Our mean value of $3.31 \mu \mathrm{mol} / \mathrm{g}$ fat-free dry weight agrees closely with that of Holbrook et al. (1979) for rectus muscle fat-free dry weight $(3 \cdot \mathrm{I} 3 \mu \mathrm{mol} / \mathrm{g})$. However Tomas et al. (1979) have given single values ( $\mu \mathrm{mol} / \mathrm{g}$ fat-free dry weight) of 3.84 (age I 9 years) and 3.64 (age 65 years), and Bilmazes et al. (1978) of $4 \cdot 2$. Part of the difference may be technical, owing to the difficulty of measuring $3-\mathrm{MeH}$ in the presence of the considerable amount of histidine normally found in muscle.

In those tissues with intermediate values the $3-\mathrm{MeH}$ is presumably derived from the muscles they contain, and the low value for cardiac muscle compared with striated muscle can be attributed to the non-methylation of histidine in cardiac myosin. In those specimens which do not clearly contain muscle, the low $3-\mathrm{MeH}$ content probably comes from the myofibrills in their blood vessels and from the intracellular network of actin and myosin (Cohen, 1979). Such a network presumably contributes the $3-\mathrm{MeH}$ in our cell preparations which are devoid of blood vessels.

These findings in the human are closely paralleled by similar investigation of the tissues in the rat (Haverberg et al. 1975). When they are taken in combination with studies defining the effect of diet which show the relative constancy of $3-\mathrm{MeH}$ excretion once intake is controlled, they should further clarify the use of $3-\mathrm{MeH}$ in studies of muscle.

This work was supported by grants from the Wellcome Trust and the MRC. The authors are indebted to Professor J. D. O. McGee for his help in obtaining the tissue specimens. The cell cultures were provided by Dr G. Christophinou.

\section{REFERENCES}

Asatoor, A. M. \& Armstrong, M. G. (1967). Biochim. biophys. Res. Comm. 26, 168.

Berry, M. N. \& Friend, D. S. (1969). J. cell Biol. 43, 506.

Bilmazes, C., Uauy, R., Haverberg, L. N., Munro, H. N. \& Young, V. R. (1978). Metabolism $27,525$.

Cohen, C. (1979). Trends biochem. Sci. 4, 73.

Haverberg, L. N., Omstedt, P. T., Munro, H. N. \& Young, V. R. (1975). Biochim. biophys. Acta $405,67$.

Holbrook, B., Gross, E. \& Irving, M. H. (1979). Br. J. Nutr. 41, I 5.

Huszar, G. \& Elzinga, M. (1972). J. biol. Chem. 247, 745.

Johnson, P., Harris, A. \& Perry, S. V. (1967). Biochem. J. 105, 361 .

Munro, H. N. (1978). Fedn Proc. Fedn Am. Socs exp. Biol. 37, 228 I.

Tallan, H., Moore, S. \& Stein, W. H. (1954). J. biol. Chem. 21 r, 927. 
Tomas, F. M., Ballard, F. J. \& Pope, L. M. (1979). Clin. Sci. 56, 341.

Williamson, D. H., Farrell, R., Kerr, A. \& Smith, R. (1977). Clin. Sci. mol. Med. 52, 527.

Young, V. R. \& Munro, H. N. (1978). Fedn Proc. Fedn Am. Socs exp. Biol. 37, 2291. 